\title{
Pengaruh Spiritual Emotional Freedom Technique terhadap Self- Acceptance Warga Binaan di Lembaga Pemasyarakatan Perempuan
}

\author{
Anjar Novitriani, Fina Hidayati \\ Universitas Islam Negeri Maulana Malik Ibrahim Malang \\ e-mail: anjar.novitriani11@gmail.com
}

\begin{abstract}
Being a prisoner often raise psychological conflicts. Prisoners often experience mental problems caused by social isolation in the prison, and it may leads to inferiority, guilty, and self-rejection. This study aims to examine the effect of Spiritual Emotional Freedom Technique (SEFT) therapy on self-acceptance of prisoners (Lembaga Pemasyarakatan Perempuan Klas II A Malang). This study used pretest-posttest control group design with purposive sampling of 15 participants for experimental group and 16 participants for control group. The results show that there was an increase from pretest to posttest with significant value of.021 $(p<.050)$. This finding indicates that there is an influence of Spiritual Emotional Freedom Technique (SEFT) therapy on self-acceptance of prisoners (Lembaga Pemasyarakatan Perempuan Klas II A Malang).
\end{abstract}

Keywords: Spiritual Emotional Freedom Technique (SEFT), self-acceptance, prisoners

\begin{abstract}
Abstrak
Menjadi warga binaan tidak jarang menimbulkan konflik-konflik psikologis dalam diri seseorang. Warga binaan seringkali mengalami masalah mental yang disebabkan oleh isolasi sosial dalam penjara, sehingga memicu munculnya rasa rendah diri, menyalahkan diri sendiri, maupun tidak menerima diri. Penelitian ini bertujuan untuk mengetahui pengaruh terapi Spiritual Emotional Freedom Technique (SEFT) terhadap tingkat penerimaan diri warga binaan Lembaga Pemasyarakatan Perempuan Klas II A Malang. Penelitian ini menggunakan pretest-posttest control group design dengan jumlah 15 responden pada kelompok eksperimen dan 16 responden pada kelompok kontrol, yang diperoleh dengan teknik purposive sampling. Hasil penelitian menunjukkan bahwa terdapat peningkatan dari pretest ke posttest dengan nilai signifikansi sebesar .021 ( $\mathrm{p}<.050)$. Hal ini menunjukkan adanya pengaruh terapi Spiritual Emotional Freedom Technique (SEFT) terhadap peningkatan penerimaan diri warga binaan Lembaga Pemasyarakatan Perempuan Klas II A Malang.
\end{abstract}

Kata Kunci: Spiritual Emotional Freedom Technique (SEFT), penerimaan diri, warga binaan

\section{Pendahuluan}

Kejahatan merupakan salah satu hal yang tidak dapat ditolerir di Indonesia. Menurut Undang-Undang Nomor 12 Tahun 1995 Pasal 1 angka 7 (tujuh) tentang Pemasyarakatan, narapidana adalah terpidana yang menjalani pidana hilang kemerdekaan di lembaga pemasyarakatan. Sedangkan dalam Pasal 1 angka 3 (tiga) Undang-Undang Nomor 12 tentang Pemasyarakatan, lembaga pemasyarakatan ("penjara") diartikan sebagai tempat untuk melaksanakan pembinaan narapidana dan anak didik pemasyarakatan (Nurdin, 2015).
Fungsi pembinaan adalah menjadikan warga binaan menyatu (integral) dengan sehat dalam bermasyarakat serta dapat berperan bebas dan bertanggungjawab (Bratamidjaja dalam Nurdin, 2015). Narapidana adalah warga negara yang tetap memiliki hak asasi manusia dan hak-hak mereka dilindungi oleh hukum. Oleh sebab itu, adanya upaya pemberdayaan dan pembinaan dilakukan untuk memulihkan rasa percaya diri dan keyakinan mereka bahwa mereka dapat berkontribusi dalam lingkungan masyarakat (Cahyono, 2014).

Amiot, Sablonniere, Terry, dan Smith dalam Salwa, Koncoro, dan Setyaningsih 
(2009) menyebutkan bahwa status menjadi narapidana adalah salah satu kejutan hidup. Kejutan hidup berupa perubahan identitas yang dialami para narapidana tidak jarang menimbulkan konflik-konflik baru pada diri narapidana. Narapidana seringkali mengalami patah mental yang disebabkan oleh isolasi sosial dalam penjara. Mereka merasa dikucilkan oleh masyarakat luar pada umumnya sehingga seringkali muncul rasa rendah diri yang hebat termasuk menyesali perbuatannya dan berulang kali menolak serta membenci "aku yang terpenjara" ini. Narapidana memiliki ketakutan akan hukuman yang sangat lama termasuk saat dibebaskan nantinya. Mereka berpikir bahwa sebagai bekas narapidana, akan sukar diterima kembali di tengah-tengah masyarakat karena noda-noda yang tidak terhapuskan itu selamanya akan melekat pada dirinya (Kartono, 2011).

Seorang narapidana dalam lembaga pemasyarakatan cenderung membutuhkan waktu untuk menerima diri, dengan status dan lingkungan barunya sebagai warga binaan. Beberapa indikator rendahnya penerimaan diri yang ditemui oleh peneliti pada warga binaan di Lapas Perempuan Malang sesuai dengan indikator yang dikemukakan oleh Berger dalam Denmark (1973). Indikator tersebut diantaranya adalah tidak percaya pada kemampuan diri, rendahnya kemampuan menyelesaikan masalah, rendah diri, merasa tidak sederajat, tidak berani menunjukkan sikap di depan orang lain, memiliki pandangan bahwa orang lain selalu menilai negatif dirinya, menyalahkan diri sendiri atas keterbatasan yang dimiliki, merasa ditolak oleh lingkungannya, serta merasa tidak nyaman dengan keberadaannya.

Hasil wawancara kepada petugas asesor Lembaga Pemasyarakatan Klas II A Malang menunjukkan bahwa warga binaan yang masih kurang dari dua tahun berada di Lembaga Pemasyarakatan Klas II A Malang cenderung memiliki masalah terkait penyesuaian diri yang kurang baik, sering memandang diri negatif, menya- lahkan diri sendiri, termasuk kemampuan menyelesaikan masalah yang kurang. Hasil wawancara awal dengan dua partisipan didapatkan bahwa sebagai warga binaan baru yang menghuni blok $\mathrm{V}$ (Pengenalan Lingkungan), mereka seringkali mengalami masalah psikologis berupa kesulitan untuk beradaptasi dengan lingkungannya, terutama dengan jadwal Lapas yang begitu padat, termasuk pembentukan etika yang ketat di dalam Lapas, serta perasaan menyalahkan diri sendiri sebab memiliki status sebagai seorang narapidana.

Data persentase hasil pra-asesmen dengan menggunakan Symptom Check List 90 (SCL90) menunjukkan bahwa aspek interpersonal sensibility yang berhubungan dengan indikator menyalahkan diri sendiri, serta tidak berani menunjukkan sikap di depan orang lain berada pada kategori sedang (48.93\%) hingga tinggi (25.53\%). Aspek paranoid ideation yang berhubungan dengan indikator memiliki pandangan bahwa orang lain selalu menilai negatif dirinya juga berada pada kategori sedang $(51.06 \%)$ hingga tinggi (25.53\%). Data tersebut menunjukkan bahwa warga binaan yang masih kurang dari dua tahun berada di Lembaga Pemasyarakatan Klas II A Malang memiliki penerimaan diri yang rendah.

Widiantoro (2015) menyebutkan dalam penelitiannya bahwa ketika penerimaan diri pada individu rendah maka individu menjadi rendah diri, memiliki ketidakpercayaan diri, cenderung berprasangka negatif pada orang lain dan lingkungan sekitarnya, mengalami kesulitan mengembangkan potensi dalam diri serta menghadapi kendala dalam pencapaian tujuan dan kebahagiaan hidupnya.

Upaya pembinaan untuk membuat narapidana dapat mencapai kemandirian serta kepercayaan diri untuk kembali ke dalam masyarakat terus dilaksanakan, termasuk upaya pembinaan psikologis berupa pemberian konseling dan pendampingan spiritual di dalam Lapas. Rendahnya penerimaan diri pada narapidana cenderung 
dapat memengaruhi segala aktivitas dan kehidupannya selama berada di Lapas terutama pada narapidana yang kurang dari dua tahun tinggal di Lapas. Dengan demikian pembinaan psikologis dilakukan melalui berbagai cara termasuk dengan menggunakan SEFT.

SEFT merupakan kepanjanganan dari Spiritual Emotional Freedom Technique yaitu teknik yang dikembangkan dengan menggabungkan aspek spiritual dengan teknik EFT (Emotional Freedom Technique) yang sudah lebih dulu berkembang (Zainuddin, 2006). Terapi SEFT merupakan teknik terapi stimulasi bagianbagian tertentu pada tubuh bagian atas berupa ketukan-ketukan ringan menggunakan ujung jari sambil merangsang elemen kognitif dengan merasakan masalah yang sedang dihadapi (Stapleton, Church, Sheldon, Porter, \& Carlopa, 2013).

Terapi Spiritual Emotional Freedom Technique (SEFT) merupakan teknik yang memiliki tujuan untuk mengembangkan kemampuan individu dalam penyembuhan dirinya. Teknik ini dapat digunakan untuk melatih individu memahami bahwa energi psikis mereka berupa perasaan, pikiran, dan emosi berperan dalam setiap pengalaman. Sehingga ketika seseorang yang percaya bahwa dirinya tidak mampu, maka hal itu akan menghalangi dirinya dalam menggunakan kemampuan yang sesungguhnya ada (Puji \& Hendriwinaya, 2015). Teknik SEFT dapat membantu melatih narapidana memahami dan menerima keadaan diri mereka sendiri, selain itu dapat melatih narapidana untuk menyadari sisi negatif dalam dirinya dan mengetahui untuk hidup bahagia dengan sisi negatif yang dimiliki, serta menjadikan pengalaman negatifnya menjadi pelajaran positif dalam hidupnya.

Individu yang dapat menerima diri diartikan sebagai seseorang yang tidak bermasalah terhadap dirinya. Individu tersebut tidak akan malu terhadap kelemahan yang ada pada dirinya, serta tidak menyalahkan kondisi-kondisi yang tidak dapat diubah (Dahri, 2008). Kalimat "tidak menyalahkan kondisi-kondisi yang tidak dapat diubah" sejalan dengan salah satu aspek keberhasilan teknik SEFT yaitu ikhlas yang artinya ridho atau menerima rasa sakit (fisik atau emosi) dengan sepenuh hati. Ikhlas dimaknai tidak mengeluh atas musibah yang sedang diterima, sebab sebenarnya yang membuat seseorang semakin sakit adalah perasaan tidak mau menerima rasa sakit atau masalah yang sedang dihadapi. Ikhlas juga dimaknai sebagai bentuk kerelaan, penerimaan atas situasi yang dihadapi (Zainuddin, 2006).

Berdasarkan paparan di atas peneliti tertarik untuk meneliti dan membahas apakah ada pengaruh dalam pemberian perlakuan berupa Terapi Spiritual Emotional Freedom Technique (SEFT) terhadap tingkat penerimaan diri warga binaan penghuni Blok V (Pengenalan Lingkungan) di Lembaga Pemasyarakatan Perempuan Klas II A Malang.

\section{Penerimaan Diri (Self-Acceptance)}

Penerimaan diri menurut Berger dalam Denmark (1973) adalah nilai-nilai dan standar diri tidak dipengaruhi lingkungan luar, keyakinan dalam menjalani hidup, bertanggungjawab terhadap apa yang dilakukan, mampu menerima kritik dan saran seobjektif mungkin, tidak menyalahkan diri atas perasaannya terhadap orang lain, menganggap dirinya sama dengan orang lain, tidak ingin orang lain menolaknya dalam kondisi apapun, tidak menganggap dirinya berbeda dari orang lain, dan tidak rendah diri. Penerimaan diri (self-acceptance) adalah konsep penting dalam memahami perkembangan kesehatan psikologis. Hal tersebut didefinisikan sebagai penerimaan individu atas semua sifat-sifatnya, baik sifat tersebut positif ataupun negatif. Penerimaan diri memungkinkan individu untuk sewajarnya mengevaluasi tepat tidaknya karakteristik yang ia miliki serta menerima segala aspek negatifnya sebagai bagian dari kepribadian mereka (Morgado, Campana, \& Tavares, 2014). 
Penerimaan diri cukup penting bagi kesehatan mental. Ketiadaan kemampuan untuk menerima diri tanpa syarat dapat membawa pada beberapa kesulitan emosional, termasuk tidak dapat mengendalikan amarah dan depresi. Seseorang yang terperangkap dalam evaluasi diri daripada penerimaan diri mungkin sangat membutuhkan curahan perhatian sumber daya personal untuk membesarkan diri dengan tujuan untuk mengimbangi perasaan kekurangan secara personal. Penerimaan diri adalah keputusan secara sadar yang dibuat individu untuk bertanggungjawab terhadap hidupnya dan menyadari bahwa mereka berada dalam kontrol keputusan yang menciptakan dunia personal mereka. Ketika individu memandang dunia dan dirinya secara sadar, mereka akan dapat menerima dirinya tanpa syarat (Carson \& Langer, 2006).

Penerimaan diri dapat dicapai dengan berhenti mengkritik dan mencela diri, menerima hal yang ada di dalam diri, serta memiliki toleransi terhadap diri yang tidak sempurna. Penerimaan merupakan sikap individu yang rela akan hal-hal yang terjadi terhadap dirinya. Rela dimaknai sebagai sikap yang positif dalam memandang dan menghadapi hal-hal yang sedang diterimanya. Sehingga individu mampu menyadari dan bertahan meski rangsangan yang datang bisa saja membuat frustrasi atau tidak diinginkan (Shepard dalam Bernard, 2013). Berdasarkan uraian di atas maka dapat disimpulkan bahwa penerimaan diri adalah sejauhmana individu dapat menyadari dan mengakui karakteristik pribadi dan menggunakannya untuk menjalani kelangsungan hidup. Penerimaan diri adalah kondisi dimana individu menyadari segala kemampuan yang dimilikinya dan dapat memanfaatkannya semaksimal mungkin, serta menyadari segala kekurangannya tanpa menyalahkan dirinya sendiri akan keterbatasan yang dimilikinya sehingga apa yang ditampilkan kepada orang lain sesuai dengan apa yang ada dalam dirinya.

\section{Terapi Spiritual Emotional Freedom Technique (SEFT)}

Spiritual Emotional Freedom Tehnique (SEFT) merupakan teknik yang dikembangkan dengan menggabungkan spiritual power dengan teknik EFT yang sudah lebih dulu berkembang (Zainuddin, 2006). EFT (Emotional Freedom Technique) terdiri dari unsur pemaparan (exposure) yang berhubungan dengan kognitif. Pemaparan (exposure) merupakan pengakuan terhadap problem yang sedang dialami. Dalam hal ini individu mengganti pikiran negatifnya, penyangkalannya terhadap problem yang dihadapi dengan sikap menerima dan pasrah. Dalam metode ini terdapat juga simulasi somatik berupa pernyataan penerimaan diri terkait problem yang dialami (fisik atau psikis) disertai dengan mempertahankan kejadian yang dialami dalam pikiran individu. Hal tersebut akan memicu stimulus somatik, kemudian bersamaan dengan hal tersebut individu menyentuh atau melakukan ketukan ringan (tapping) pada bagian-bagian tertentu di tubuh bagian atas menggunakan ujung jari.

Hui, Liu, dan Makris dalam Church, De Asis, dan Brooks (2012) menemukan bahwa akupuntur mengirimkan sinyal secara langsung kepada amigdala dan struktur otak lainnya dalam sistem limbik yang memproses rasa takut. Teknik ini juga dipahami secara luas memengaruhi bagian otak yang terlibat dalam hyperarousal termasuk amigdala, dan studi terbaru yang menggunakan teknik Emotional Freedom Techniques (EFT) mengindikasikan adanya penurunan pada aktivitas amigdala dan hipokampus (Stapleton, Church, Sheldon, Porter, \& Carlopa, 2013).

Terapi SEFT merupakan suatu terapi yang menitikberatkan pada bagian sisi spiritual seseorang (Cortright dalam Puji \& Hendriwinaya, 2015). Terapi SEFT terdiri dari tiga tahapan yaitu The Set Up, The Tune In, dan The Tapping. The Set Up adalah niat atau doa kepasrahan yang ditujuan kepada Tuhan. Tujuannya adalah untuk meminimalisasi perlawanan psikolo- 
gis berupa pikiran negatif spontan atau keyakinan bawah sadar negatif. The Tune In adalah tahapan yang berhubungan dengan kognitif dimana tahap ini dilakukan dengan cara merasakan rasa sakit yang sedang dialami, atau memikirkan peristiwa spesifik tertentu yang dapat membangkitkan emosi negatif yang ingin dihilangkan. The Tapping adalah mengetuk ringan bagian-bagian tubuh tertentu pada tubuh bagian atas dengan ujung jari sambil terus melakukan Tune In.

Berdasarkan uraian di atas dapat disimpulkan bahwa terapi Spiritual Emotional Freedom Technique (SEFT) merupakan terapi yang dilakukan dengan cara mengetuk ringan ujung jari dengan stimulasi bagian-bagian tertentu pada tubuh bagian atas sambil merangsang elemen kognitif dengan merasakan masalah yang sedang dihadapi. Termasuk di dalamnya ada unsur pernyataan penerimaan diri berupa afirmasi positif yang dapat menurunkan halangan (keyakinan bawah sadar negatif) yang sedang dihadapi.

\section{Metode Penelitian}

Penelitian ini menggunakan pendekatan eksperimen dengan desain eksperimen ulang (pretest-posttest control group design). Desain ini melakukan pengukuran sebelum (pretest) dan sesudah (posttest) pemberian treatment pada kelompok eksperimen serta pemberian plasebo kepada kelompok kontrol (Seniati, Yulianto, \& Setiadi, 2011). Variabel yang diukur perubahannya dalam penelitian ini adalah penerimaan diri, sedangkan perlakuan yang diberikan adalah Terapi SEFT (Spiritual Emotional Freedom Technique). Teknik pengambilan sampel pada penelitian ini menggunakan purposive sampling dengan jumlah populasi 533 orang. Purposive sampling adalah teknik penentuan sampel dengan pertimbangan tertentu. Pemilihan sekelompok subjek dengan purposive sampling didasarkan atas ciri-ciri tertentu yang diterapkan berdasarkan tujuan penelitian (Sugiyono, 2013).
Secara umum partisipan harus memiliki beberapa kriteria sebagai berikut: a) Warga binaan yang berada di blok V (Pengenalan Lingkungan) Lembaga Pemasyarakatan Perempuan Klas II A Malang; b) Baru menjalani masa hukuman di Lembaga Pemasyarakatan Perempuan Klas II A Malang kurang dari 2 tahun; c) Warga binaan yang memiliki nilai asesmen awal dari sedang hingga tinggi dengan menggunakan SCL90 pada aspek hostility, interpersonal sensitivity, dan paranoid ideation.

Partisipan penelitian adalah warga binaan Lembaga Pemasyarakatan Perempuan Klas II A Malang. Partisipan yang terlibat dalam penelitian eksperimen ini berjumlah 31 warga binaan dengan 15 orang berada di kelompok eksperimen dan 16 orang lainnya berada di kelompok kontrol. Penentuan partisipan penelitian didasarkan pada pendapat Roscoe (dalam Sekaran, 2006) bahwa untuk penelitian eksperimental sederhana dengan kontrol eksperimen yang ketat, penelitian yang sukses adalah mungkin dengan ukuran sampel kecil antara 10 sampai dengan 20 .

Prosedur eksperimen penelitian ini terdiri dari dua tahap yaitu tahap persiapan dan tahap pelaksanaan. Tahap persiapan merupakan tahap dimana peneliti mempersiapkan segala keperluan untuk mendukung terlaksananya penelitian dengan baik. Segala keperluan seperti izin, tempat, kesediaan waktu yang diberikan pihak Lapas, penyesuaian waktu pemateri, serta modul pelatihan. Pada tahap pelaksanaan, peneliti melaksanakan kegiatan eksperimen selama 20 hari dengan pertemuan tatap muka sebanyak 4 kali. Total waktu setiap pertemuan kurang lebih 75 - 90 menit.

Setiap pertemuan diisi oleh seorang praktisi di bidang SEFT (Spiritual Emotional Freedom Technique). Partisipan diberikan lembar monitoring untuk menuliskan hal-hal apa saja yang dianggap sebagai problem. Berdasarkan apa yang telah dituliskan, partisipan akan dibimbing untuk menggunakan terapi SEFT sebagai 
upaya mengatasi problem yang sedang dialami.

Penelitian ini menggunakan skala penerimaan diri dari Berger's selfacceptance scale pada tahun 1973 dengan mengubah pilihan alternatif jawaban menjadi empat pilihan respon yaitu sangat setuju (SS), setuju (S), tidak setuju (TS), sangat tidak setuju (STS) dengan mempertimbangkan pemahaman, usia dan latar belakang pendidikan subjek yang berbedabeda. Hasil data akan dianalisis menggunakan Uji Independent Sample T Test (Aisyah, 2015).

Perlakuan plasebo juga diberikan kepada kelompok kontrol berupa Focus Group Discussion (FGD) terkait penerimaan diri (self-acceptance) dalam satu kali pertemuan dengan durasi sekitar 75 menit.

\section{Hasil Penelitian dan Pembahasan}

Hasil analisa tingkat penerimaan diri (self-acceptance) warga binaan sebelum mendapat perlakuan (hasil pretest) cenderung berada pada kategori sedang. Kecenderungan tersebut terlihat dari kedua kelompok eksperimen maupun kelompok kontrol dengan persentase masing-masing
$60 \%$ dan $44 \%$ sebagaimana tertera pada tabel 1 dan tabel 3. Pada kelompok eksperimen terdapat 9 dari 15 partisipan yang memiliki tingkat penerimaan diri sedang, sedangkan pada kelompok kontrol partisipan yang memiliki tingkat penerimaan diri sedang ada 7 dari total 16 partisipan. Selain kategori sedang, terdapat partisipan dengan kategori penerimaan diri rendah yaitu 4 partisipan $(27 \%)$ pada kelompok eksperimen dan 6 partisipan (38\%) pada kelompok kontrol. Berdasarkan hasil pemaparan di atas dapat disimpulkan bahwa tingkat penerimaan diri warga binaan Lembaga Pemasyarakatan memiliki kecenderungan dari tingkat sedang ke rendah.

Pada tabel 2, hasil yang diperoleh setelah dilakukan pemberian perlakuan (hasil posttest) berupa terapi Spiritual Emotional Freedom Technique (SEFT) menunjukkan tingkat penerimaan diri (selfacceptance) warga binaan yang menjadi kelompok eksperimen cenderung berada pada kategori tinggi dengan persentase $40 \%$. Pada kelompok eksperimen terdapat 6 dari 15 partisipan yang memiliki tingkat penerimaan diri tinggi. Selain kategori tinggi, partisipan di kelompok eksperimen

Tabel 1

Kategori Variabel dengan Hasil Skor Pretest Kelompok Eksperimen

\begin{tabular}{lccc}
\hline \multirow{2}{*}{ Kategori } & \multirow{2}{*}{ Kriteria } & \multicolumn{2}{c}{ Pretest } \\
\cline { 3 - 4 } & & Frekuensi & Persentase \\
\hline Sangat Rendah & $\mathrm{X} \leq 50.73$ & 0 & $0 \%$ \\
Rendah & $50.73<\mathrm{X} \leq 55.57$ & 4 & $27 \%$ \\
Sedang & $55.57<\mathrm{X} \leq 60.42$ & 9 & $60 \%$ \\
Tinggi & $60.42<\mathrm{X} \leq 65.26$ & 0 & $0 \%$ \\
Sangat Tinggi & $\mathrm{X}>65.26$ & 2 & $13 \%$ \\
Total & & 15 & $100 \%$ \\
\hline
\end{tabular}

Tabel 2

Kategori Variabel dengan Hasil Skor Posttest Kelompok Eksperimen

\begin{tabular}{lccc}
\hline \multirow{2}{*}{ Kategori } & \multirow{2}{*}{ Kriteria } & \multicolumn{2}{c}{ Posttest } \\
\cline { 3 - 4 } & & Frekuensi & Persentase \\
\hline Sangat Rendah & $\mathrm{X} \leq 55.90$ & 4 & $7 \%$ \\
Rendah & $55.90<\mathrm{X} \leq 60.32$ & 4 & $27 \%$ \\
Sedang & $60.32<\mathrm{X} \leq 64.74$ & 6 & $27 \%$ \\
Tinggi & $64.74<\mathrm{X} \leq 69.74$ & 0 & $40 \%$ \\
Sangat Tinggi & $\mathrm{X}>69.74$ & 15 & $0 \%$ \\
Total & & & $100 \%$ \\
\hline
\end{tabular}


yang memiliki tingkat kategori sedang ada 4 partisipan $(27 \%)$.

Analisis dalam penelitian ini menggunakan Uji Independent Sample T Test dimana hasil analisa akan membuktikan apakah hipotesis yang diajukan dalam penelitian ini diterima atau tidak. Berdasarkan hasil pada tabel 6 didapatkan nilai signifikansi Levene's Test sebesar .750 (p>.05) yang artinya data ini bersifat homogen. Jika data homogen maka lajur signifikansi yang dibaca adalah equal variances assumed, signifikansi pada lajur tersebut menunjukkan nilai .021 ( $\mathrm{p}<.050)$. Pengujian hipotesis yang menggunakan Independent Sample T Test diperoleh hasil yang signifikan dengan perolehan skor $.021<.050$ yang artinya hipotesis (Ha) diterima. Hal ini menunjukkan adanya perubahan atau pengaruh sebelum dan sesudah subjek diberikan perlakuan berupa terapi Spiritual Emotional Freedom Technique (SEFT).
Hasil tersebut juga mengindikasikan adanya perbedaan antara kelompok kontrol dan kelompok eksperimen. Selain itu, perubahan tingkat penerimaan diri dapat dilihat dari hasil hitung mean empirik skor posttest antara kelompok eksperimen dan kontrol. Hasil mean pada Independent Sample $T$ Test menunjukkan bahwa mean kelompok eksperimen (4.5333) lebih tinggi daripada mean kelompok kontrol (.6875). Selain mean pada Independent Sample $T$ Test perubahan tingkat penerimaan diri juga dapat dilihat dari hasil hitung mean empirik skor posttest antara kelompok eksperimen dan kontrol. Pada tabel 5 dapat diketahui nilai mean empirik skor posttest kelompok eksperimen sebesar 62.53 sedangkan nilai mean empirik kelompok kontrol sebesar 58.12. Jadi, dapat disimpulkan bahwa mean kelompok eksperimen lebih besar dari mean empirik kelompok kontrol.

Tabel 3

Kategori Variabel dengan Hasil Skor Pretest Kelompok Kontrol

\begin{tabular}{lccc}
\hline \multirow{2}{*}{ Kategori } & \multirow{2}{*}{ Kriteria } & \multicolumn{2}{c}{ Pretest } \\
\cline { 3 - 4 } & & Frekuensi & Persentase \\
\hline Sangat Rendah & $\mathrm{X} \leq 44.47$ & 0 & $0 \%$ \\
Rendah & $44.47<\mathrm{X} \leq 53.11$ & 6 & $38 \%$ \\
Sedang & $53.11<\mathrm{X} \leq 61.75$ & 7 & $44 \%$ \\
Tinggi & $61.75<\mathrm{X} \leq 70.39$ & 2 & $13 \%$ \\
Sangat Tinggi & $\mathrm{X}>70.39$ & 1 & $6 \%$ \\
Total & & 16 & $100 \%$ \\
\hline
\end{tabular}

Tabel 4

Kategori Variabel dengan Hasil Skor Posttest Kelompok Kontrol

\begin{tabular}{lccc}
\hline \multirow{2}{*}{ Kategori } & \multirow{2}{*}{ Kriteria } & \multicolumn{2}{c}{ Posttest } \\
\cline { 3 - 4 } & & Frekuensi & Persentase \\
\hline Sangat Rendah & $\mathrm{X} \leq 47.04$ & 1 & $6 \%$ \\
Rendah & $47.04<\mathrm{X} \leq 54.43$ & 5 & $31 \%$ \\
Sedang & $54.43<\mathrm{X} \leq 61.81$ & 6 & $38 \%$ \\
Tinggi & $61.81<\mathrm{X} \leq 69.20$ & 2 & $13 \%$ \\
Sangat Tinggi & $\mathrm{X}>69.20$ & 16 & $13 \%$ \\
Total & & & $100 \%$ \\
\hline
\end{tabular}

Tabel 5

Hasil Uji Statistik Deskriptif

\begin{tabular}{lccccc}
\hline & N & Min & Max & Mean & Std. Deviation \\
\hline KE_Pretest & 15 & 52 & 69 & 58.00 & 4.840 \\
KE_Posttest & 15 & 54 & 69 & 62.53 & 4.422 \\
KK_Pretest & 16 & 47 & 79 & 57.44 & 8.641 \\
KK_Posttest & 16 & 47 & 72 & 58.12 & 7.384 \\
Valid N(listwise) & 15 & & & & \\
\hline
\end{tabular}


Tabel 6

Hasil Uji Independen Sample T Test dengan Gain Score

\begin{tabular}{cccccc}
\hline \multirow{2}{*}{ Gain } & Equal variances assumed & \multicolumn{2}{c}{$\begin{array}{c}\text { Levene's Test for } \\
\text { Equality of Variances }\end{array}$} & \multicolumn{2}{c}{ t-test for Equality of Mean } \\
\cline { 3 - 6 } & & $\mathrm{F}$ & Sig. & $\mathrm{T}$ & Sig. (2-tailed) \\
\hline \multirow{3}{*}{ Equal variances not assumed } & & .750 & 2.450 & .021 \\
& & & & 2.456 & .020 \\
\hline
\end{tabular}

Perbedaan besar nilai mean yang diperoleh ini menguatkan bahwa pengaruh perlakuan pada kelompok eksperimen lebih efektif dibandingkan perlakuan plasebo yang diberikan pada kelompok kontrol. Berdasarkan hasil analisa tersebut dapat disimpulkan bahwa hipotesis (Ha) diterima. Artinya, terapi Spiritual Emotional Freedom Technique (SEFT) memiliki pengaruh signifikan dalam peningkatan penerimaan diri (self-acceptance) pada warga binaan Lembaga Pemasyarakatan Klas II A Malang. Selain itu hampir seluruh subjek yang mengikuti pelatihan terapi Spiritual Emotional Freedom Technique (SEFT) menunjukkan perubahan positif berupa peningkatan skor penerimaan diri.

Hasil penelitian ini sesuai dengan penelitian terkait yang menggunakan terapi Spiritual Emotional Freedom Technique (SEFT) sebagai treatment. Seperti penelitian yang dilakukan Aulianita dan Sudarmiati (2015) menunjukkan bahwa teknik Spiritual Emotional Freedom Technique (SEFT) didapati mampu membantu menurunkan kecemasan serta direkomendasikan sebagai terapi alternatif untuk mengatasi kecemasan wanita klimakterium. Hasil penelitian eksperimen Church, De Asis, dan Brooks (2012) dengan subjek para mahasiswa tingkat pertama yang memiliki level depresi sedang hingga tinggi yang telah diukur melalui Beck's Depression Inventory (BDI) menunjukkan adanya penurunan tingkat depresi pada kelompok eksperimen setelah diberikan treatment berupa Emotional Freedom Techniques (EFT) daripada kelompok kontrol yang tidak mendapatkan treatment.

Proses pelatihan terapi Spiritual Emotional Freedom Technique (SEFT) ini sangat berkaitan dengan penerimaan diri pada warga binaan Lembaga Pemasyarakatan Perempuan Klas II A Malang. Keterampilan yang diajarkan dan disampaikan selama pelatihan merupakan upaya untuk mengurangi pikiran-pikiran negatif dan lebih melihat kemampuan diri yang dimiliki, dengan demikian partisipan dapat melihat adanya hal positif yang didapatkan meski dalam keadaan terburuk sekalipun. Partisipan dapat memberikan respon terhadap goncangan kehidupan yang mereka alami dengan lebih baik dan menyikapinya dengan lebih positif. Hal ini senada dengan pernyataan Chebat (dalam Dahri, 2008) yang menyatakan bahwa menerima diri bukan berarti pasrah dan menyerah terhadap segala kondisi dan keadaan yang sedang dialami, apalagi kalau keadaan tersebut adalah keadaan yang sulit dan tidak mengenakkan. Menerima diri berarti menyerahkan segala sesuatunya, baik halhal yang menyenangkan berupa harapan, kebahagiaan, prestasi, kesuksesan, dan sebagainya maupun hal-hal yang tidak menyenangkan berupa kepedihan, kekhawatiran, ancaman, masa depan yang tidak pasti bahkan mungkin suram, dan sebagainya kepada sang pencipta.

Warga binaan yang memiliki penerimaan diri rendah seringkali tidak mempercayai dirinya sendiri yang akhirnya membuat mereka menghadapi kendala dalam pencapaian tujuan hidupnya. Terapi SEFT dapat membantu melatih warga binaan untuk menyadari sisi negatif dalam dirinya serta menjadikan pengalaman negatifnya sebagai pelajaran positif dalam hidup.

Aspek lain dalam terapi SEFT yang turut serta memengaruhi keberhasilannya 
adalah ikhlas, pasrah, dan khusyu'. Ketiga aspek tersebut memiliki hubungan erat dengan tahapan Set Up dan Tune In. Ikhlas dan pasrah memiliki pengaruh terhadap Set $U p$ atau pada saat partisipan melakukan afirmasi berupa pernyataan menerima segala hal yang sedang dialami tanpa penyangkalan dan menyerahkan sepenuhnya kepada Tuhan. Sedangkan khusyu' memiliki makna konsentrasi penuh terhadap apa yang sedang diperbuat memengaruhi proses Tune In dalam mengingat, membayangkan, maupun merasakan masalah yang sedang dihadapi.

Kalimat afirmasi dalam terapi Spiritual Emotional Freedom Technique (SEFT) berupa kalimat penerimaan diri yang disertai dengan mempertahankan kejadian yang dialami dalam pikiran akan memicu stimulus somatik, kemudian bersamaan dengan hal tersebut melakukan ketukan ringan (tapping) pada bagian-bagian tertentu pada tubuh bagian atas dapat merangsang banyak aktivitas dalam otak seperti mengirimkan sinyal secara langsung kepada amigdala dan struktur otak lainnya dalam sistem limbik yang memproses rasa takut. Selain itu, cara tersebut dapat menurunkan tingkat kortisol yang secara signifikan berkorelasi dengan depresi, kecemasan, dan keadaan psikologis lainnya (Church, De Asis, \& Brooks, 2012).

\section{Simpulan dan Saran}

\section{Simpulan}

Dari pemaparan hasil penelitian ini dapat disimpulkan bahwa Terapi Spiritual Emotional Freedom Technique (SEFT) dapat meningkatkan penerimaan diri warga binaan, sebab diperoleh hasil yang menunjukkan tingkat penerimaan diri (selfacceptance) warga binaan Lembaga Pemasyarakatan Perempuan Klas II A Malang cenderung berada pada kategori sedang hingga tinggi setelah diberikan perlakuan berupa Terapi Spiritual Emotional Freedom Technique (SEFT). Hasil analisa Uji Independent Sample T
Test juga menunjukkan skor sebesar .021 $(\mathrm{p}<.05)$.

Aspek Spiritual Emotional Freedom Technique (SEFT) berupa ikhlas, pasrah, dan khusyu' memiliki pengaruh besar terhadap keberhasilan terapi. Ketiga aspek tersebut berhubungan erat dengan tahapan SEFT yaitu Set Up dan Tune In. Terapi Spiritual Emotional Freedom Technique (SEFT) sendiri merupakan terapi yang merangsang elemen kognitif dengan merasakan masalah yang sedang dihadapi. Termasuk di dalamnya ada unsur pernyataan penerimaan diri berupa afirmasi positif yang dapat menurunkan halangan (keyakinan bawah sadar negatif) yang sedang dihadapi.

\section{Saran}

Berdasarkan pada hasil penelitian ini, disarankan kepada pihak Lembaga Pemasyarakatan untuk mempertimbangkan Terapi Spiritual Emotional Freedom Technique (SEFT) sebagai salah satu kegiatan peningkatan skill untuk meminimalisasi masalah-masalah psikologis yang mungkin muncul dan dialami oleh warga binaan. Saran bagi peneliti selanjutnya jika melakukan penelitian serupa agar melibatkan populasi yang lebih luas. Apabila peneliti selanjutnya menggunakan dua kelompok dalam pengambilan data (kelompok eksperimen dan kelompok kontrol), ada baiknya pemberian perlakuan plasebo terhadap kelompok kontrol tidak memiliki sangkut paut apapun dengan modul pelatihan yang ditujukan untuk kelompok eksperimen, baik berupa materi maupun metode pelatihannya. Sehingga materi atau perlakuan yang diberikan kepada kelompok kontrol benarbenar berbeda dan terlepas dari variabel yang akan diukur perubahannya oleh peneliti. 


\section{Daftar Pustaka}

Aisyah, E. N. (2015). Statistik inferensial parametrik: Contoh penelitian untuk riset keuangan strategik dengan alat analisis SPSS. Universitas Negeri Malang: Penerbit IKIP Malang.

Aulianita, Y., \& Sudarmiati, S. (2015). Pengaruh spiritual emotional freedom technique terhadap kecemasan wanita klimakterium di RW. 6 Kelurahan Pedalangan Kecamatan Banyumanik Kota Semarang Jawa Tengah. Prosiding Seminar Nasional Keperawatan Komunitas "Peran Perawat dalam Pelayanan Kesehatan Primer menuju Masyarakat Ekonomi ASEAN" Semarang, 7 November 2013.

Bernard, M. E. (Ed). (2013). The strength of self-acceptance: Theory, practice, and research. New York, NY: Springer Science+Business Media.

Cahyono, A. S. (2014). Pemberdayaan dan pengembangan keterampilan warga binaan di Lembaga Pemasyarakatan Klas IIB Tulungagung. Jurnal Universitas Tulungagung Bonorowo, 2(1), 110.

Carson, S. H., \& Langer, E. J. (2006). Mindfulness and self-acceptance. Journal of Rational-Emotive \& Cognitive-Behavior Therapy, 24(1), 29-43.

Church, D., De Asis, M. A., \& Brooks, A. J. (2012). Brief group intervention using emotional freedom techniques for depression in college students: A randomized controlled trial. Depression Research and Treatment, 2012, 17.

Dahri, A. (2008). Penerimaan diri dan dukungan sosial kaitannya dengan kebahagiaan hidup lansia purna tugas (Tesis tidak diterbitkan).
Program Magister Psikologi

Fakultas Psikologi Universitas Gadjah Mada.

Denmark, K. L. (1973). Self-acceptance and leader effectiveness. Journal of Extension, 11(4), 6-12.

Kartono, K. (2011). Patologi sosial (Jilid 1). Jakarta: Rajawali Pers.

Morgado, F. F., Campana, A. N., \& Tavares, M. D. C. (2014). Development and validation of the self-acceptance scale for persons with early blindness: The SASEB. PlosOne, 9(9). doi: 10.1371/journal.pone.0106848.

Nurdin, W. H. (2015). Realisasi hak narapidana untuk menyampaikan keluhan atas perlakuan sesama narapidana di Lembaga Pemasyarakatan Klas IIA Wirogunan (Skripsi tidak diterbitkan). Program Peradilan dan Penyelesaian Sengketa Hukum Fakultas Hukum Universitas Atma Jaya, Yogyakarta.

Puji, P., \& Hendriwinaya, V. W. (2015). Terapi transpersonal. Buletin Psikologi, 23(2), 92-102.

Salwa, U., Kuncoro, J., \& Setyaningsih, R. (2009). Dukungan sosial keluarga dan persepsi terhadap vonis dengan penerimaan diri narapidana Lembaga Pemasyarakatan Klas II A Wanita Semarang. Proyeksi, 5(2), 79-89.

Sekaran, U. (2006). Metodologi penelitian untuk bisnis. Jakarta: Salemba Empat.

Seniati, L., Yulianto, A., \& Setiadi, B. (2011). Psikologi eksperimen. Jakarta: PT Indeks.

Stapleton, P., Church, D., Sheldon, T., Porter, B., \& Carlopio, C. (2013). Depression symptoms improve after successful weight loss with EFT (Emotional Freedom Techniques): A randomized 
Pengaruh Spiritual Emotional Freedom Technique terhadap Self-Acceptance Warga Binaan di Lembaga Pemasyarakatan Perempuan (Anjar Novitriani \& Fina Hidayati)

controlled trial. ISRN Psychiatry, $2013,1-7$.

Sugiyono. (2013). Metode penelitian kuantitatif, kualitatif dan $R \& D$. Bandung: Alfabeta.

Widiantoro, W. (2015). Meningkatkan pemahaman penerimaan diri melalui permainan "menggambar jari” sebagai upaya meningkatkan kesejahteraan psikologis pada warga binaan. Seminar Psikologi \& Kemanusiaan Psychology Forum UMM.

Zainuddin, A. F. (2006). Spiritual Emotional Freedom Technique (SEFT) for Healing + Success + Happiness + Greatness. Jakarta: Afzan Publishing. 
Psympathic, Jurnal Ilmiah Psikologi Juni 2018, Vol. 5, No. 1, Hal. : 1-12 